\title{
Fabrication of MnOx/MWCNTs-GC Nanocatalyst for Oxygen Evolution Reaction
}

\author{
Islam M. Al-Akraa*, Yaser M. Asal, Amr M. Arafa \\ Department of Chemical Engineering, Faculty of Engineering, The British University in Egypt, Cairo \\ 11837, Egypt \\ *E-mail: islam.ahmed@bue.edu.eg; islam0886@yahoo.com
}

doi: $10.20964 / 2018.09 .23$

Received: 13 April 2018 / Accepted: 2 June 2018 / Published: 5 August 2018

\begin{abstract}
Manganese oxide (MnOx) and multiwalled carbon nanotubes (MWCNTs) are intended to modify the GC electrode for oxygen evolution reaction (OER). Optimization of MnOx loading is carried out and the deposition of 55 cycles was sufficient to obtain the highest activity toward OER. The stability of the catalyst is enhanced by the addition of MWCNTs. As a result, an amount of $22 \mathrm{kWh} / \mathrm{Kg}$ of $\mathrm{O}_{2}$ of energy is saved. Several techniques including cyclic voltammetry, linear sweep voltammetry, chronoamperometry, chronopotentiometry, field-emission scanning electron microscopy, and energy dispersive X-ray spectroscopy will be combined to track the catalyst activity and to determine its morphology and composition.
\end{abstract}

Keywords: Oxygen evolution reaction; Water electrolysis; Manganese oxide; Carbon nanotubes.

\section{$\underline{\text { FULL TEXT }}$}

(C) 2018 The Authors. Published by ESG (www.electrochemsci.org). This article is an open access article distributed under the terms and conditions of the Creative Commons Attribution license (http://creativecommons.org/licenses/by/4.0/). 